UNIVERSIDADE DE SÃO PAULO
HOSPITAL DE REABILITAÇÃO DE ANOMALIAS CRANIOFACIAIS

OSCAR STANGHERLIN GOMES

Influence of bone-anchored maxillary protraction on secondary alveolar bone graft status in unilateral cleft lip and palate

Influência da protração maxilar com ancoragem óssea no status do enxerto ósseo alveolar secundário em fissura labiopalatina unilateral 



\title{
Influence of bone-anchored maxillary protraction on secondary alveolar bone graft status in unilateral cleft lip and palate
}

\section{Influência da protração maxilar com ancoragem óssea no status do enxerto ósseo alveolar secundário em fissura labiopalatina unilateral}

\author{
Dissertação apresentada ao Hospital de \\ Reabilitação de Anomalias Craniofaciais da \\ Universidade de São Paulo para obtenção do \\ título de Mestre em Ciências da Reabilitação. \\ Área de Concentração: Fissuras Orofaciais e \\ Anomalias Relacionadas
}

Orientadora: Profa. Dra. Daniela Gamba Garib Carreira

Coorientadora: Dra. Marília Sayako Yatabe loshida 


\section{UNIVERSIDADE DE SÃO PAULO \\ HOSPITAL DE REABILITAÇÃO DE ANOMALIAS CRANIOFACIAIS}

\section{R. Silvio Marchione, 3-20}

Caixa Postal: 1501

17012-900 - Bauru - SP - Brasil

Telefone: (14) 3235-8000

Prof. Dr. Vahan Agopyan - Reitor da USP

Prof. Dr. José Sebastião dos Santos - Superintendente do HRAC /USP

Autorizo, exclusivamente, para fins acadêmicos e científicos, a reprodução total ou parcial desta Tese.

Nome/assinatura

Bauru, de de

\section{Gomes, Oscar Stangherlin}

G585i Influência da protração maxilar com ancoragem óssea no status do enxerto ósseo alveolar secundário em fissura labiopalatina unilateral / Oscar Stangherlin Gomes, Bauru, 2018.

45p.; il.; $30 \mathrm{~cm}$.

Dissertação (Mestrado - Fissuras Orofaciais e Anomalias Relacionadas) - Hospital de Reabilitação de Anomalias Craniofaciais, Universidade de São Paulo.

Orientador: Profa. Dra. Daniela Gamba Garib Carreira

Descritores: 1.Procedimentos de ancoragem ortodôntica 2.Enxerto de osso alveolar 3.Fenda labial 


\title{
FOLHA DE APROVAÇÃO
}

\section{Oscar Stangherlin Gomes}

Dissertação apresentada ao Hospital de Reabilitação de Anomalias Craniofaciais da Universidade de São Paulo para a obtenção do título de Mestre.

Área de Concentração: Fissuras Orofaciais e Anomalias Relacionadas

Aprovado em:

\author{
Banca Examinadora
}

Prof. Dr.

Instituição

Prof. Dr.

Instituição

Prof.(a) Dr.(a)
Instituição (Orientador)

Prof.(a) Dr.(a)

Presidente da Comissão de Pós-Graduação do HRAC-USP

Data de depósito da dissertação junto à SPG: 



\section{AGRADECIMENTOS}

À Deus,

Por brindar a mim e a minha família com saúde, boas companhias e amizades, por nos cuidar durante viagens, sobretudo nas estradas, e por sempre nos mostrar o caminho da bondade.

Aos meus amados pais, Valéria e Oscar,

Na história de vocês eu apareci de repente, mudei seus planos e adicionei responsabilidade ao seu dia a dia. Agradecer sua dedicação a mim e aos meus irmãos é insuficiente perto de toda a renúncia e empenho que tiveram para criar seus três filhos de um modo presente, com cuidado e afeto inigualáveis. Pai, obrigado pelos conselhos e por sempre nos encorajar. Mãe, minha primeira professora de ortodontia, trabalhar ao seu lado é leve e prazeroso, uma honra que poucos tem. Amo vocês.

À minha amada companheira, Martha,

Encontrá-la e tê-la em minha vida foi meu maior presente, e depois disso, conquistar algo importante só tem graça se você estiver ao meu lado. Seu carinho é combustível para os dias fáceis e difíceis. Sua presença me acalma e conforta. Seu sorriso me apaixona a cada dia. Seu abraço é a tradução de aconchego, e o seu cheiro, de lar.

Aos meus queridos irmãos, Victor e Vinícius,

Vocês são o orgulho que não me cabe no peito, são pessoas do bem, com coração aberto e verdadeiro. São minha companhia escolhida por Deus e minha inspiração para ser uma pessoa cada vez melhor.

Às nossas colaboradoras Ana Paula e Leidemar,

Por estarem sempre empenhadas em oferecer aos nossos pacientes uma experiência melhor a cada dia, pela organização e pelo engrenado trabalho em equipe.

Às secretárias Zezé, Luci, Ana Regina e à estaticista Flávia, 

Sempre prontas para ajudar um aluno perdido. Obrigado por todas as instruções, orientações e pela dedicação à pós-graduação.

A todos os funcionários do HRAC,

Com quem passei muito tempo nas clínicas, corredores, laboratórios. Obrigado pelas boas conversas, ensinamentos e prazerosa companhia.

Aos meus professores,

Sou extremamente grato por todo o tempo que dedicaram a me transmitir conhecimento, direta e indiretamente, do maternal à pós-graduação. Absorver e seguidamente difundir conhecimento é atitude das mais nobres. Ao meu ver, o professor é a peça mais importante da sociedade à longo prazo.

À minha admirada orientadora, Profa. Daniela,

Gostariam todos os alunos de pós-graduação que seus orientadores fossem como você (e aqui me permito escrever esse pronome). Sua orientação, professora, merece um processo seletivo próprio (sorte a minha que ainda não o tem). Para que os alunos que estão lendo não fiquem bravos comigo, eu explico... A Professora Daniela não se zanga, não cobra (cada um sabe o que tem que fazer!), não perde a paciência (é um poço dela), está sempre disponível apesar de sua agenda disputadíssima, é compreensiva, exala conhecimento científico e paz de espírito, ensina com tranquilidade e em poucas palavras, corrige artigos em um piscar de olhos, é extremamente respeitada pela sua ciência, e além de tudo, é uma pessoa prazerosíssima de se gastar um tempo em prosa. Acabou? Não, depois disso tudo ainda tenho que completar, ela é humilde! Me atrevo a dizer que se todos os professores no mundo fossem como Daniela Garib, já teríamos conquistado outros planetas. Resumindo, a professora Dani é simplesmente uma orientadora que você não quer decepcionar! Querida professora, registro aqui minha enorme admiração à docente que me incentivou a continuar os estudos após a especialização, você me inspira a ser melhor como ortodontista e como ser humano. 

"A essência do conhecimento consiste em aplicá-lo, uma vez possuído"

Confúcio 



\section{RESUMO}

Gomes OS. Influência da protração maxilar com ancoragem óssea no status do enxerto ósseo alveolar secundário em fissura labiopalatina unilateral. Bauru.

Dissertação [Mestrado em Ciências da Reabilitação] - Hospital de Reabilitação de Anomalias Craniofaciais, Universidade de São Paulo; 2018.

Introdução: A protração maxilar ancorada em miniplacas (BAMP) utilizando elásticos intermaxilares mostrou resultados ortopédicos adequados em pacientes de 10 a 14 anos de idade. Em pacientes com fissura labiopalatina, houve favorecimento estético e funcional durante o crescimento, reduzindo a possibilidade ou magnitude de cirurgia ortognática futura. Objetivo: Avaliar os efeitos da protração maxilar ancorada em miniplacas (BAMP) sobre o status do enxerto ósseo alveolar secundário (SABG) em pacientes com fissura labiopalatina unilateral (UCLP). Métodos: O grupo experimental (EG) foi composto por 26 pacientes com UCLP e idade média de 11,7 anos submetidos à terapia com SABG e BAMP. Os exames de tomografia computadorizada de feixe cônico (CBCT) foram realizados 3 a 6 meses após a cirurgia de enxerto ósseo, antes (T1) e ao final de 12 meses de tratamento com BAMP (T2). O grupo controle (CG) foi composto por 24 pacientes com o mesmo tipo de fissura submetidos apenas ao enxerto ósseo alveolar secundário, pareados por idade inicial e sexo com o EG. No grupo controle, os exames de CBCT foram realizados 6 meses (T1) e 12 meses (T2) após a cirurgia de SABG. Secções axiais de CBCT foram analisadas utilizando o método de Garib et al. (2017). Comparações intra e intergrupos foram realizadas utilizando os testes Wilcoxon e Mann-Whitney ( $p$ $<5 \%)$. Resultados: Não foram encontradas diferenças intergrupos em T1 e T2. O grupo experimental apresentou aumento do escore do enxerto de T1 para T2. Nenhuma diferença interfases foi encontrada no grupo controle. Conclusões: Apesar das cargas aplicadas na maxila, nenhum dano ao osso alveolar enxertado foi observado após a terapia com BAMP em pacientes com UCLP.

Palavras-chave: Procedimentos de ancoragem ortodôntica, Enxerto de osso alveolar, Fenda labial, Fissura palatina. 



\begin{abstract}
Gomes OS. Influence of bone-anchored maxillary protraction on secondary alveolar bone graft status in unilateral cleft lip and palate. Bauru. Dissertação [Mestrado em Ciências da Reabilitação] - Hospital de Reabilitação de Anomalias Craniofaciais, Universidade de São Paulo; 2018.
\end{abstract}

Introduction: Bone-anchored maxillary protraction (BAMP) using intermaxillary elastics has shown adequate orthopedic results in patients from 10 to 14 years of age. In cleft lip and palate, patients were favored esthetically and functionally during growth, having reduced the possibility or magnitude of future orthognathic surgery. Objective: To evaluate the effects of bone anchored maxillary protraction (BAMP) on the status of the secondary alveolar bone graft (SABG) in patients with unilateral cleft lip and palate (UCLP). Methods: The experimental group (EG) comprised 26 patients with UCLP and a mean age of 11.7 years submitted to SABG and BAMP therapy. Cone-beam computed tomography (CBCT) exams were taken 3 to 6 months after SABG and prior to BAMP (T1) and at the end of 12 months of therapy (T2). The control group (CG) was composed by 24 patients with UCLP submitted only to SABG, matched by initial age and sex with the EG. In the control group, CBCT exams were performed 6 months (T1) and 12 months (T2) after SABG surgery. CBCT axial sections were analyzed using the method by Garib et al. (2017) in both time points. Intra and intergroup comparisons were performed using Wilcoxon and Mann-Whitney tests $(p<5 \%)$. Results: No intergroup differences were found at T1 and T2. The experimental group showed an increase of graft score from T1 to T2. No interphase differences were found for graft score in the control group. Conclusions: In spite of loads applied to the maxilla, no harm on the grafted alveolar bone was observed after BAMP therapy in patients with UCLP.

Keywords: Orthodontic anchorage procedures, Alveolar bone grafting, Cleft lip, Cleft palate. 

SUMMARY

1 INTRODUCTION AND LITERATURE REVIEW

2 OBJECTIVE

$3 \quad$ ARTICLE 27

$4 \quad$ FINAL CONSIDERATIONS $\quad 41$

REFERENCES 



\section{INTRODUCTION AND LITERATURE REVIEW}

Patients with cleft, in the first year of life, face surgical procedures for the correction of deformities on the lip and palate. These surgeries are carried out early with the intention of providing the patient better shape, esthetics, function and social integration from early childhood. However, in individuals with complete cleft, antagonistically to the aforementioned beneficial effects, a progressive maxillary deficiency is observed throughout growth, impairing middle face projection and outlining a skeletal Class III facial pattern that characterizes an inadequate sagittal relationship of the dental arches. This counterpart of the primary surgeries can seriously affect facial esthetics, contributing negatively to the self-esteem of the young person in development (NORMANDO; SILVA FILHO; CAPELOZZA FILHO, 1992; SOUSA; DEVARE; GHANSHANI, 2009). It has been estimated that $48 \%$ of patients with unilateral complete cleft and $65 \%$ of complete bilateral need orthognathic surgery to correct maxillary deficiency (DASKALOGIANNAKIS; MEHTA, 2009).

Literature presents three important methods of orthopedic treatment for skeletal Class III: Chincup therapy, Facemask and, more recently, the use of Class III elastics anchored to bone miniplates. The first, however, does not promote effects on the maxilla, being mostly used on prognathism and has limited outcome on a predominantly vertical growth pattern because even with forces on postero-superior direction, almost always results in downward mandible rotation (DE CLERCK; PROFFIT, 2015). The second method, rapid maxillary expansion associated with the reverse traction of the maxilla with facemask, is broadly used as an orthopedic procedure for the management of maxillary deficiency (BACCETTI et al., 1998). In spite of promoting maxillary advancement, this therapy has a small magnitude effect, stimulating only 1 to $2 \mathrm{~mm}$ of forward displacement more than normal growth in the period (CEVIDANES et al., 2010). Due to anchoring to the upper teeth, maxillary protraction inevitably causes undesirable side effects as buccal inclination of the upper incisors while the lower incisors are lingually tipped by mental support of the mask. In addition, this therapy involves a bulky removable extra oral appliance and depends on the cooperation of the patient (DE CLERCK et al., 2009; DE CLERCK; PROFFIT, 2015). 
The third and final method employs skeletal anchoring devices, which were initially advocated in orthodontics to maximize the skeletal effect of orthopedic therapies or to create a stationary anchorage for tooth movement. Several miniplate designs have been developed. The Bollard miniplates have been shown effective for maxillary protraction and the installation procedure is well tolerated by the patient and feasible under local anesthesia (CORNELIS et al., 2008; DE CLERCK; SWENNEN, 2011). Bone-anchored maxillary protraction (BAMP) was first described in 2009 (DE CLERCK et al., 2009) as new proposal for the orthopedic management of sagittal maxillary deficiency. It includes installation of four miniplates on the jawbones. Two miniplates are installed on the maxilla, at the lower region of the zygomatic process, the other two are installed on the mandible between canines and lateral incisors. The miniplate hook-heads are interconnected by Class III intermaxillary elastics, producing low force tension from $100 \mathrm{~g}$ raising gradually to $250 \mathrm{~g}$ (Figure 1). Firstly, the treatment was performed in 3 patients aged 10 to 11 years who presented skeletal Class III with maxillary deficiency. Cone-beam computed tomography was performed before installation surgery and after 1 year of therapy. Patients were instructed to use the intermaxillary elastics 24 hours a day, with daily replacement. Preliminary results demonstrated considerable advance in the zygomaticomaxillary region with Class III malocclusion correction and a marked improvement in facial profile (Figures 2 and 3 ).

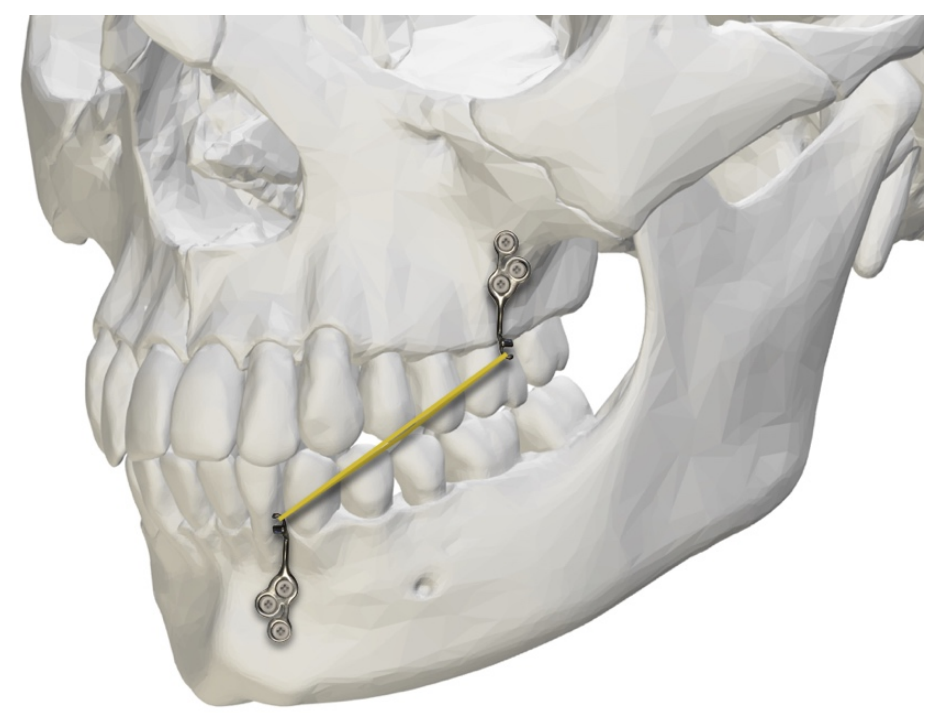

(Part of image downloaded from http://lifesciencedb.jp/bp3d/ and modified in Keynote 8.0.1, Apple, U.S.A)

Figure 1- Illustration of De Clerck's treatment protocol for Class III with intraoral elastics anchored to miniplates. 


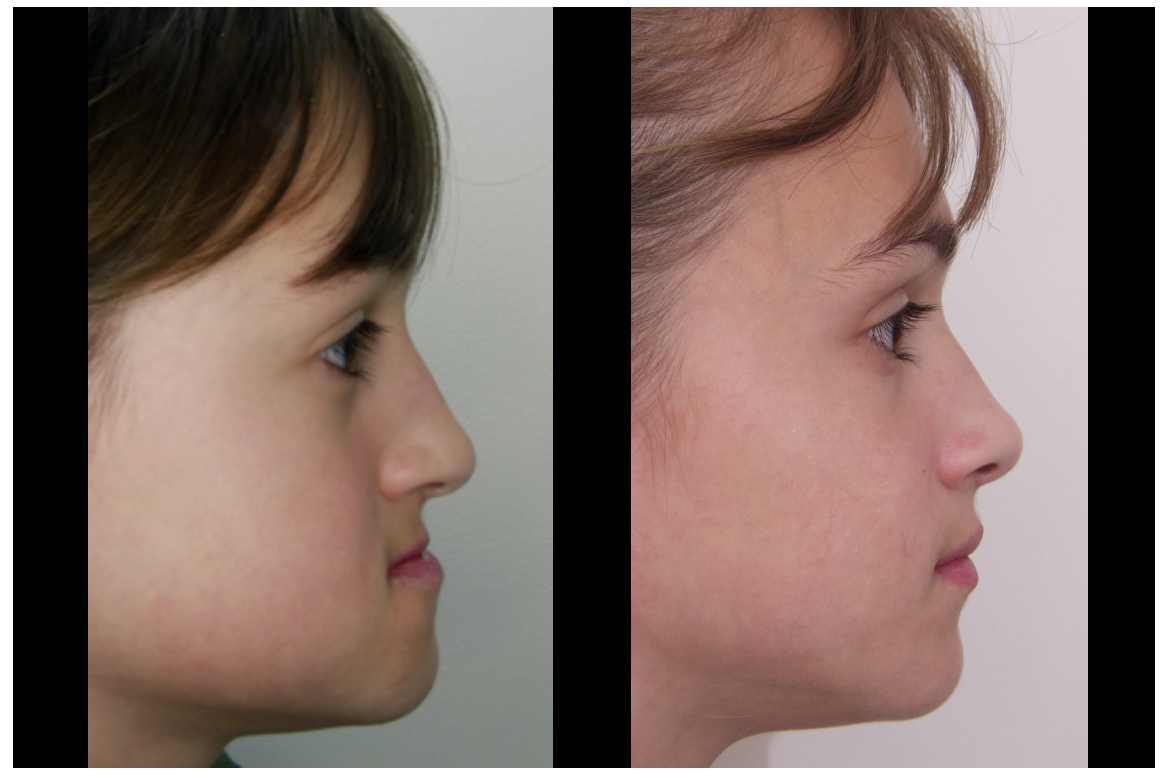

(Source: DE CLERCK et al., 2009).

Figure 2- Patient without cleft with skeletal Class III, before and after bone-anchored maxillary protraction.

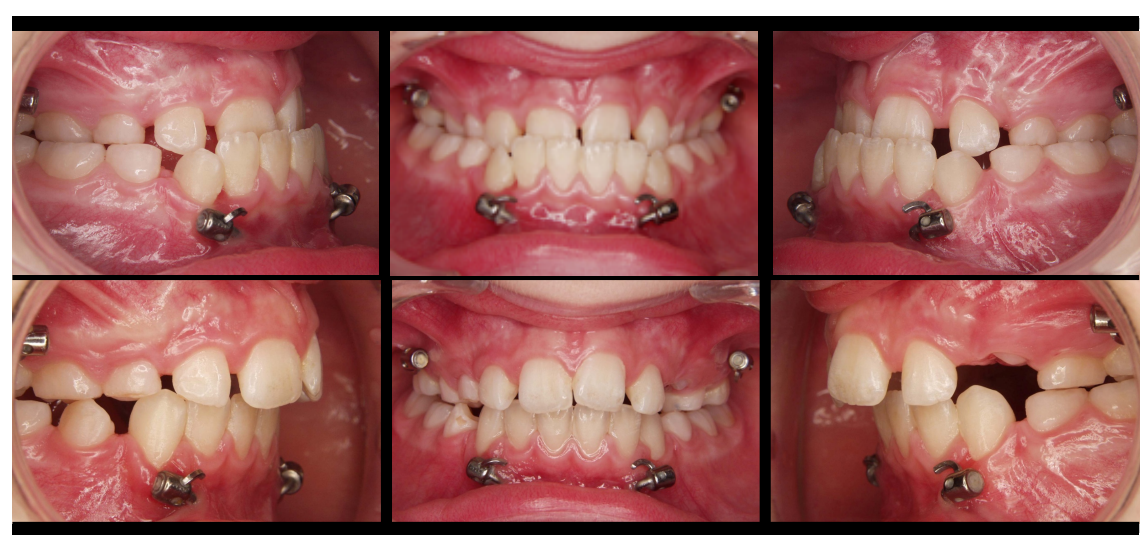

(Source: DE CLERCK et al., 2009).

Figure 3- Intraoral photos before BAMP therapy (upper line) and 1 year after (lower).

In 2010, the same authors performed a new work, now with 21 patients, in which the good results of the protraction technique were confirmed. Compared to the control group, BAMP protocol produced maxillary advancements of up to $6 \mathrm{~mm}$, attested in cone-beam computed tomography images, which is equivalent to approximately 2 times more than the best outcomes with the facemask (CEVIDANES et al., 2010). Another interesting effect of this protocol is the unprecedented restriction of mandibular anterior displacement by remodeling of the glenoid fossa (BACCETTI et al., 2011). 
After proven success for this orthopedic approach, questions arose about the effects of BAMP therapy in patients with complete unilateral clefts, type that mostly impacts maxillary growth; and excellent results were also found, showing the feasibility of the technique for correction of maxillomandibular discrepancies also in cleft patients (YATABE et al., 2017b; YATABE et al., 2017a). In these preliminary studies large individual variability was found on the success of maxillary protraction. The authors cite influence of age, sutural maturation and facial growth pattern should be investigated in the results of BAMP therapy.

Described by Boyne and Sands, (BOYNE; SANDS, 1972) the Alveolar Bone Graft $(A B G)$ is now essential part of cleft rehabilitation always when the alveolar ridge is involved. Many benefits have been aggregated to its use. When the ABG fills the cleft completely, it joins the adjacent maxillary bone segments and returns to the maxilla the characteristic of being a single bone, forming a continuous dental arch and ensuring better stability, yet not impairing the eruption of nearby teeth. Such feats can be observed as early as 3 months after surgery (SILVA FILHO et al., 2000). Besides these, other important advantages are obtained during the rehabilitation: Dental movements in the cleft region, elimination of buconasal communications, facilitation of prosthetic rehabilitations with better gingival esthetics, formation of better periodontium around the adjacent teeth ensuring greater longevity, and better support for the lip and nasal wing (BERGLAND; SEMB; ABYHOLM, 1986; BOYARSKIY; CHOI; PARK, 2006; TURVEY et al., 1984).

The ABG can be performed at different times, and may receive the following classifications: primary (performed early, during deciduous dentition and may cause restriction of maxillary growth), secondary (when done between 9 and 12 years of age, before the adjacent canine irruption), late secondary or tertiary (after the eruption of the permanent canine, indicated to reduce periodontal bone loss and favor prosthetic rehabilitation) (TURVEY et al., 1984; ÅBYHOLM; BERGLAND; SEMB, 1981; SANTIAGO; SCHUSTER; LEVY-BERCOWSKI, 2014). The most accepted with best long-term results is the secondary $A B G$ (SABG). It favors eruption and preservation of the cleft-adjacent teeth without interfering on midface's development as maxillary growth potential decreases around its age-range of execution (SILVA FILHO et al., 2000; TURVEY et al., 1984; ÅBYHOLM; BERGLAND; SEMB, 1981). 
Autogenous bone is the material of choice for the ABG worldwide. Some of the various donor areas that can be used are: tibia, chin, iliac crest, rib, and skull cap. Among these, the cancellous portion of the iliac crest is often preferred for providing a good amount of material, being rich in bone cells and allowing good vascularization (BOYNE; SANDS, 1972; SANTIAGO; SCHUSTER; LEVY-BERCOWSKI, 2014; ZOUHARY, 2010). Despite good success, the search for synthetic substitutes for the autogenous bone is persistent. Many materials have been studied, hoping the patient would no longer be subjected to additional invasive procedures such as graft removal (BOYNE; SANDS, 1972). Along this race, bone morphogenetic protein (BMP), in its recombinant rhBMP-2 form, has currently been one of the main substitutes for autogenous $A B G$. BMPs are part of the TGF- $B$ (transforming growth factor-beta) superfamily of proteins and act in the development of bones and cartilage. The option of grafting with rhBMP-2 is relatively recent but studies have evaluated it as a good autogenous bone substitute with success rates similar or even better than the gold standard (LIANG et al., 2017; WU et al., 2018; HAMMOUDEH et al., 2017; KANG, 2017).

One question arises when thinking about the possible effects of BAMP therapy on cleft patients. The secondary alveolar bone graft stands as the thinnest part of the reconstructed maxilla and could represent a fragile region under compression forces delivered by an orthopedic treatment. Therefore, the following article will approach the status of the SABG on cleft patients submitted to BAMP therapy. 



\section{OBJECTIVE}

The aim of this study was to assess the effects of bone-anchored maxillary protraction therapy on the status of secondary alveolar bone graft performed with rhBMP-2 in patients with complete unilateral cleft. The null hypothesis is that there is no difference on bone morphology of the alveolar graft in patients submitted or not to BAMP therapy. 

Note: The following work was prepared according to the guidelines for submission to the American Journal of Orthodontics and Dentofacial Orthopedics. 



\section{ARTICLE}

\section{Introduction}

Skeletal anchorage recently opened a new window for facial orthopedics, demonstrating significant anterior displacement of the midface with Class III malocclusion correction and improvement on the profile, along with restriction of anterior displacement of the mandible through posterior remodeling of the glenoid fossa. ${ }^{1,2,3}$ Maxillary deficiency in UCLP (unilateral cleft lip and palate) was also adequately managed with BAMP (bone-anchored maxillary protraction) therapy during late mixed or early permanent dentition with significantly earlier facial improvement compared to the Le Fort 1 surgery. ${ }^{4}$ Additionally, bone-anchored protraction in UCLP was found to be symmetric and similar to non-cleft patients in both jaws. ${ }^{5,6}$

Secondary alveolar bone grafting ( $S A B G$ ) with autogenous bone from the iliac crest is the gold standard with adequate outcomes. ${ }^{7}$ Since the introduction of the alveolar bone graft, ${ }^{8}$ materials have been studied to replace its autogenous character, hoping the patient would then no longer be subjected to additional invasive procedures. Along this race, bone morphogenetic protein (BMP), in its recombinant rhBMP-2 form, has been one of the main substitutes for autogenous SABG. The option of grafting with rhBMP-2 is relatively recent but studies have evaluated it as a good autogenous bone substitute with success rates similar or even better than the gold standard..$^{9,10,11,12}$

The bone bridge formed by SABG that reestablishes the maxilla as a single bone can be determined as a region of greater fragility due to its smaller thickness when compared to the rest of the maxillary arch. Could sagittal forces of compression influence the newly formed bone? No previous work has investigated such presumption. It is therefore of great interest to evaluate the effects of BAMP therapy on the status of the grafted region. The aim of this study was to assess the outcome of bone-anchored maxillary protraction technique on the status of secondary alveolar bone graft performed with rhBMP-2 in patients with UCLP. The null hypothesis is that there is no difference on alveolar graft status in patients submitted or not to BAMP therapy. 


\section{Methods}

Ethics committee approval was obtained from the Hospital for Rehabilitation of Craniofacial Anomalies, University of São Paulo, Brazil, (process number 65573717.8.0000.5441). This retrospective longitudinal study comprised two study groups from a single rehabilitation center. The experimental group (EG) was composed by 26 patients with a mean age of 11.7 years (17 males and 9 females). Inclusion criteria were: patients with complete unilateral cleft who underwent boneanchored maxillary protraction therapy, already submitted to secondary alveolar bone grafting procedure at the same center, Goslon occlusal index of 3, 4 or 5 (mild, moderate and severe maxillary deficiency, respectively). ${ }^{13}$ CBCT scans were taken before (T1) and right after (T2) BAMP therapy, which was carried out on a period of 18 months. Bony plates were installed 3 to 6 months after SABG surgery. The elastic tension was applied 15 days after plate installation surgery and corresponded to 100 grams in the first month and increased gradually reaching 250 grams on the third month of usage. During BAMP therapy, patients with overbite wore an acrylic bite plate in the maxillary arch.

The control group (CG) comprised 24 patients with UCLP (16 males and 8 females) and a mean age of 10.5 years. Individuals in this group underwent secondary alveolar bone graft surgery but were not submitted to BAMP therapy. Inclusion criteria for this group was: same cleft type of EG, absence of syndromes or other associated craniofacial anomalies, presence of at least two CBCT exams in the HRAC-USP database taken after SABG surgery at most similar time-range to EG.

Each of the groups had their SABG surgery performed by one surgeon only. All patients were treated at the same rehabilitation center. Patients from EG group had alveolar graft surgery performed with rhBMP-2. Patients in CG group had SABG performed with rhBMP-2 $(n=12)$ or autogenous cancellous bone from the iliac crest $(n=12)$.

CBCT examinations were obtained using 3D i-CAT system (Imaging Sciences International, Hatfield, $\mathrm{Pa}$ ) using a field of view of $13 \times 16 \mathrm{~cm}$, a $0.4 \mathrm{~mm}$ voxel size and 8.9s. Analysis was performed using 3D Slicer software (Slicer, Ann Arbor, Michigan, USA). The standardization of the head positon followed the long axis of the cleft contralateral maxillary central incisor in the vertical position on both sagittal and coronal views (Figure 1). 
Three axial sections were generated at the maxilla 3, 6 and 9 millimeters apically from the cementoenamel junction of the incisor used for standardization (Figure 2). The three axial slices were chosen to represent the thirds of the root and were called cervical, middle and apical, respectively.

Score attribution was performed by two examiners previously calibrated following the methodology described by Garib et al. ${ }^{14}$ (Figure 3). One of the examiners evaluated images in two different times within an interval of 15 days.

Intrarater and inter-rater agreements were determined using kappa statistics. Mann-Whitney test was used for intergroup comparison (CG x EG in T1 and T2). For intragroup comparison Wilcoxon test was performed (EG - T1 x T2 and CG - T1 x T2). Statistical analysis was done using SigmaPlot 11.0 software (Systat Software $\mathrm{GmbH}$, Erkrath, Germany). Results were regarded for $\mathrm{p}<0.05$.

\section{Results}

The power test was calculated considering a minimum intergroup difference of $20 \%$, with $5 \%$ alpha value and a sample size of 25 patients per group. The statistical power found was $90 \%$.

Both intra and inter-rater agreements were excellent (Table 1).

In the experimental group, score increase was observed between T1 and T2. No interphase differences were found for the SAGB score in the control group (Table 2).

No intergroup differences were found for T1 and T2 absolute scores (Table 3). Interphase changes were different between groups with EG showing a slight increase in the SABG score at cervical and middle regions of central incisor root (Table 3 ).

\section{Discussion}

Successful oral rehabilitation of complete cleft lip and palate depends on adequate outcomes of SABG. In the past decades, many studies have assessed alveolar graft success based on two-dimensional images using score scales. ${ }^{15,16,17}$ Currently, tomographic scans are available with the advantage of demonstrating bone width in the grafted area. CBCT axial slices allow a labiolingual evaluation of the graft success with adequate reproducibility and less superimposed structures and distortions. ${ }^{14}$ Our study used the qualitative scale by Garib et al. ${ }^{14}$ modifying only the tooth used as reference for axial sections. Considering the evaluation was performed 
before comprehensive orthodontic treatment, the contralateral central incisor was used as reference for obtaining the axial slices instead the cleft side central incisor which was frequently rotated and distoangulated.

Once the sample mean initial age was younger than in the study by Garib, ${ }^{14}$ intraosseous canine was occasionally an issue. If bone presence was observed continuously around an irrupting canine, the image was rated. However, in some of the axial images the follicle of the irrupting cleft side canine prevented the observation of a bony bridge, and the image was not rated in order to avoid possible false-negative evaluation. As result, 15 out of 297 total images (14 images from the cervical and 1 from the middle sites) were excluded. The method used in this study for evaluating SABG outcomes showed excellent intrarater and interrater agreements (0.91) in accordance to previous studies using CBCT scans. ${ }^{14,18,19}$

The experimental group showed score increase from $\mathrm{T} 1$ to $\mathrm{T} 2$ at the cervical and middle root thirds (Table 2). In other words, an increase in bone quality was observed in EG from 6 to 24 months post-surgery. One limitation of our study is the mixed types of bone graft in the control group. However, studies have suggested bone morphogenetic protein and autogenous graft have equivalent outcomes when compared for SABG. ${ }^{9,10,20}$ The apical third maintained a stable score over time. A previous study showed that alveolar bone grafting using rhBMP-2 induces a slower bone formation compared to autogenous bone grafting. ${ }^{21}$ Six months after surgery, rhBMP-2 may not show complete potential bone formation, while after 12 months outcomes are similar to autogenous bone graft. No interphase changes on SABG were observed in the control group where the scores were maintained from 6 to 12 moths after SABG surgery. Autogenous bone grafting, used in half of CG was reported as having an earlier formation on the cleft and therefore, demonstrating an adequate bone formation already at 6 months post-surgery. ${ }^{21}$

CG and EG were compatible at $\mathrm{T} 1$ as intergroup comparison showed no initial statistical difference for any of the levels assessed (Table 3). In this phase, most of the sites had a bone bridge between the major and minor maxillary segments (scores 3 and 4). The exception was the cervical third of the experimental group which lacked a bony bridge and had bone covering only the neighboring teeth to the cleft (score 2). When considering T2, no differences between groups were found at any level. Both experimental and control groups demonstrated an adequate bone bridge at the cervical, middle and apical root thirds. Adequate graft formation and development 
may be due to the proper age of the surgical procedure, along with technique and surgeon expertise. ${ }^{15,22}$

Interphase changes were distinct between groups at cervical and middle root thirds (Table 3). At 3 and $6 \mathrm{~mm}$ levels, the experimental group presented an increase in the SABG score while the status remained unchanged in the control group. These differences might be explained by the longer observation time in EG (18 months) compared to CG (6 months). Although different time observation between groups seems a limitation, these outcomes point that alveolar bone grafting is not compromised by maxillary protraction loads and no harm was offered by BAMP therapy. These results agree with a previous study demonstrating that BAMP is successfully conducted after SABG surgery with negligible asymmetry in the maxillary protraction. ${ }^{4}$ The maxilla of the patient with cleft appears to be protruded as an undivided bone after SABG with no compression influence on the graft area along therapy. Future randomized clinical studies with alveolar bone graft assessment after completion of comprehensive orthodontic treatment should be performed to confirm these results.

\section{Conclusions}

In spite of loads applied to the maxilla, no harm on the grafted alveolar bone was observed after BAMP therapy in patients with UCLP. 


\section{Article References}

1. De Clerck HJ, Cornelis MA, Cevidanes LH, Heymann GC, Tulloch CJF.

Orthopedic Traction of the Maxilla With Miniplates: A New Perspective for Treatment of Midface Deficiency. J. Oral Maxillofac. Surg. 2009;67(10):2123-9.

2. Cevidanes L, Baccetti T, Franchi L, McNamara JA, De Clerck H. Comparison of two protocols for maxillary protraction: Bone anchors versus face mask with rapid maxillary expansion. Angle Orthod. 2010;80(5):799-806.

3. Baccetti T, De Clerck HJ, Cevidanes LH, Franchi L. Morphometric analysis of treatment effects of bone-anchored maxillary protraction in growing Class III patients. Eur. J. Orthod. 2011;33(2):121-5.

4. Garib D, Yatabe M, de Souza Faco RA, Gregório L, Cevidanes L, de Clerck H. Bone-anchored maxillary protraction in a patient with complete cleft lip and palate: $A$ case report. Am. J. Orthod. Dentofacial Orthop. 2018;153(2):290-7.

5. Yatabe M, Garib DG, Faco RA de S, et al. Bone-anchored maxillary protraction therapy in patients with unilateral complete cleft lip and palate: 3-dimensional assessment of maxillary effects. Am. J. Orthod. Dentofac. Orthop. 2017;152(3):32735.

6. Yatabe M, Garib D, Faco R, et al. Mandibular and glenoid fossa changes after bone-anchored maxillary protraction therapy in patients with UCLP: A 3-D preliminary assessment. Angle Orthod. 2017;87(3):423-31.

7. Bergland O, Semb G, Abyholm FE. Elimination of the residual alveolar cleft by secondary bone grafting and subsequent orthodontic treatment. Cleft Palate $\mathrm{J}$. 1986;23(3):175-205.

8. Boyne PJ, Sands NR. Secondary bone grafting of residual alveolar and palatal defects. Oral Maxillofac Surg 1972;30(2):87-92.

9. Liang F, Yen SLK, Imahiyerobo T, et al. Three-Dimensional Cone Beam Computed Tomography Volumetric Outcomes of rhBMP-2/Demineralized Bone Matrix versus Iliac Crest Bone Graft for Alveolar Cleft Reconstruction. Plast. Reconstr. Surg. 2017;140(4):767-74.

10. Wu C, Pan W, Feng C, et al. Grafting materials for alveolar cleft reconstruction: a systematic review and best-evidence synthesis. Int. J. Oral Maxillofac. Surg. 2018;47(3):345-56.

11. Hammoudeh JA, Fahradyan A, Gould DJ, et al. A comparative analysis of recombinant human bone morphogenetic protein-2 with a demineralized bone matrix versus iliac crest bone graft for secondary alveolar bone grafts in patients with cleft lip and palate: Review of 501 cases. Plast. Reconstr. Surg. 2017;140(2):318e-325e.

12. Kang NH. Current Methods for the Treatment of Alveolar Cleft. Arch. Plast. Surg. 2017 May;44(3):188-193 
13. Mars M, Plint DA, Houston WJ, Bergland O, Semb G. The Goslon Yardstick: a new system of assessing dental arch relationships in children with unilateral clefts of the lip and palate. Cleft Palate J. 1987;24(4):314-22.

14. Garib D, Massaro C, Yatabe M, Janson G, Lauris JRP. Mesial and distal alveolar bone morphology in maxillary canines moved into the grafted alveolar cleft: Computed tomography evaluation. Am. J. Orthod. Dentofac. Orthop. 2017;151(5):869-77.

15. Russell K, Long RE, Daskalogiannakis J, et al. A Multicenter Study Using the SWAG Scale to Compare Secondary Alveolar Bone Graft Outcomes for Patients With Cleft Lip and Palate. Cleft Palate-Craniofacial J. 2016;53(2):180-6.

16. Hynes PJ, Earley MJ. Assessment of secondary alveolar bone grafting using a modification of the Bergland grading system. Br. J. Plast. Surg. 2003;56(7):630-6.

17. Peamkaroonrath C, Godfrey K, Chatrchaiwiwatana S. New clinical method for alveolar bone graft evaluation in cleft patients: A pilot study. Cleft Palate-Craniofacial J. 2011;48(3):286-92.

18. Suomalainen A, Åberg T, Rautio J, Hurmerinta K. Cone beam computed tomography in the assessment of alveolar bone grafting in children with unilateral cleft lip and palate. Eur. J. Orthod. 2014;36(5):603-11.

19. Wangsrimongkol T, Manosudprasit M, Pisek $P$, Sutthiprapaporn $P$, Somsuk T. Alveolar bone graft evaluation agreement using cone beam computed tomography in cleft lip and palate patients: a pilot study. J. Med. Assoc. Thai. 2013;96 Suppl 4:S3643.

20. Canan LW, Da Silva Freitas R, Alonso N, Tanikawa DYS, Rocha DL, Coelho JCU. Human bone morphogenetic protein-2 Use for maxillary reconstruction in cleft lip and palate patients. J. Craniofac. Surg. 2012;23(6):1627-33.

21. Alonso N, Tanikawa DYS, Freitas R da S, Canan, Lady, Ozawa TO, Rocha DL. Evaluation of Maxillary Alveolar Reconstruction Using a Resorbable Collagen Sponge with Recombinant Human Bone Morphogenetic Protein-2 in Cleft Lip and Palate Patients. Tissue Eng. Part C Methods 2010;16(5):1183-9.

22. Trindade-Suedam IK, Da Silva Filho OG, Carvalho RM, et al. Timing of alveolar bone grafting determines different outcomes in patients with unilateral cleft palate. $J$. Craniofac. Surg. 2012;23(5):1283-6. 


\section{Article Figure Captions}

Figure 1 - Standardization of CBCT scan keeping the long axis of the upper central incisor contralateral to the cleft coincident to the vertical sagittal and coronal reference lines.

Figure 2 - Axial CBCT slices from EG patient. A, B and C - 3, 6 and 9 millimeters apically to the cementoenamel junction, respectively.

Figure 3 - Illustration representing the scores attributed to tomographic reconstructions (Garib et al., 2017).

0 - No bone bridge mesially to the maxillary canine and no visible bone covering on both roots of adjacent teeth;

1 - No bone bridge mesially to the maxillary canine and presence of visible bone covering only one of the adjacent roots;

2 - No bone bridge mesially to the maxillary canine and presence of visible bone covering both roots of the adjacent teeth;

3 - Narrow alveolar bone bridge mesially to canine. Bone bridge was considered narrow when corresponded to less than $50 \%$ of the labiolingual thickness of the present adjacent canine image;

4 - Complete alveolar bone bridge present mesially to the maxillary canine. Bone bridge was considered adequate when corresponded to more than $50 \%$ of the labiolingual thickness of the present adjacent canine image. 


\section{Article Figures}

Figure 1

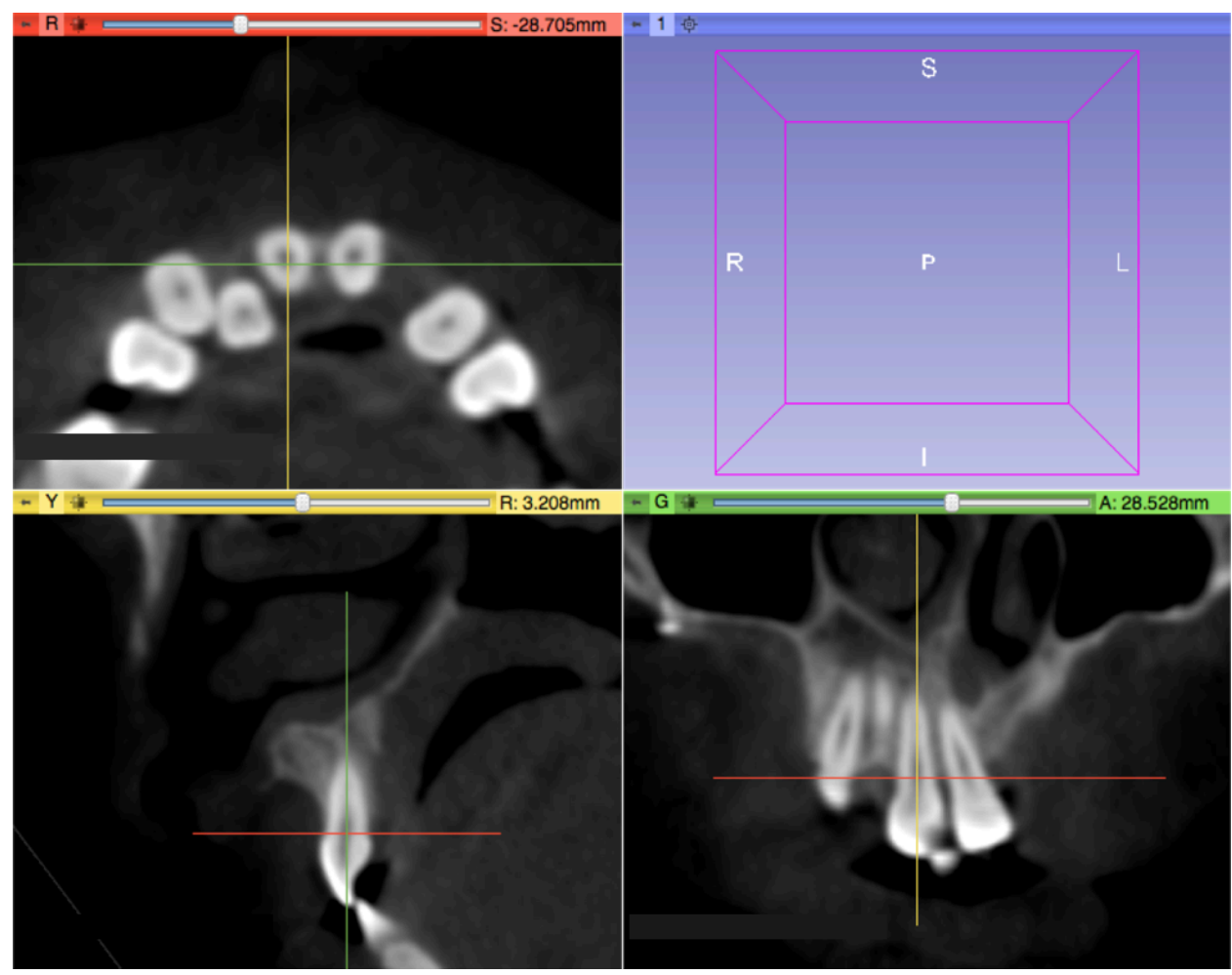


36

Figure 2

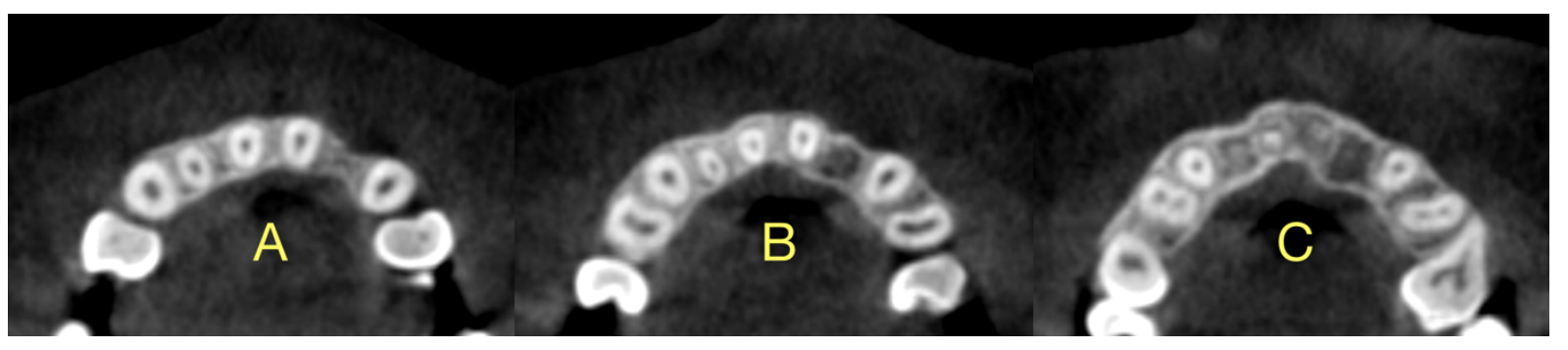


Figure 3

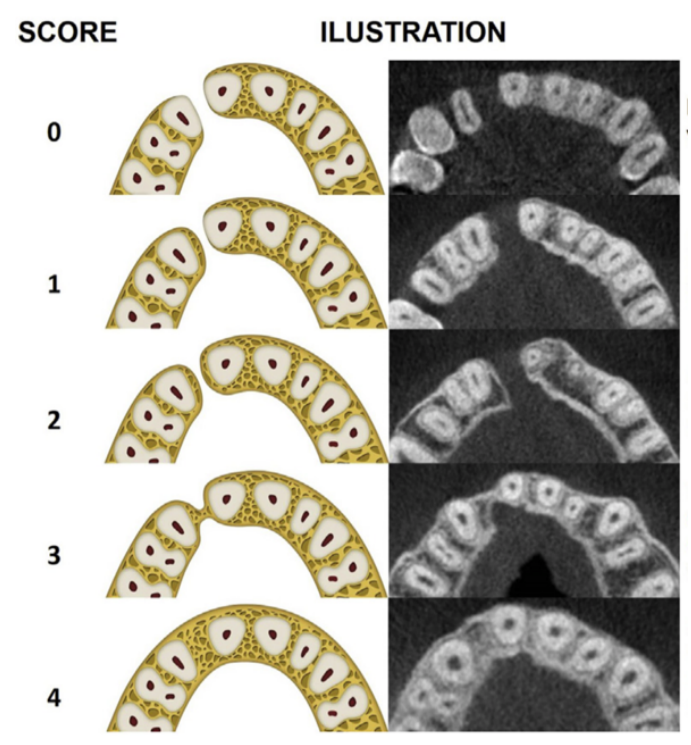


Article Tables

Table 1

\begin{tabular}{lcc}
\hline \multicolumn{1}{c}{ Comparison } & Reproducibility & $\mathbf{9 5 \%} \mathbf{~ C l}$ \\
\hline Examiner 1 x examiner 1 & $0.91^{*}$ & $0.84-0.99$ \\
Examiner 1 x examiner 2 & $0.91^{*}$ & $0.84-0.99$ \\
*Excellent reproducibility. & & \\
\hline
\end{tabular}

Table 1 - Intrarater and interrater reliabilities by kappa index 
Table 2

\begin{tabular}{|c|c|c|c|c|c|c|}
\hline & & & Median & $25 \%$ & $75 \%$ & $p$ \\
\hline & $3 \mathrm{~mm}$ & T1 & 2 & 2 & 3.8 & \\
\hline & & T2 & 4 & 3 & 4 & $<0.001^{*}$ \\
\hline \multirow[t]{6}{*}{ EG } & $6 \mathrm{~mm}$ & T1 & 3 & 2 & 4 & \\
\hline & & $\mathrm{T} 2$ & 4 & 3 & 4 & $0.042^{*}$ \\
\hline & $9 \mathrm{~mm}$ & $\mathrm{~T} 1$ & 4 & 2 & 4 & \\
\hline & & $\mathrm{T} 2$ & 4 & 3.5 & 4 & 0.375 \\
\hline & $3 \mathrm{~mm}$ & $\mathrm{~T} 1$ & 4 & 1 & 4 & \\
\hline & & T2 & 4 & 2.5 & 4 & 0.625 \\
\hline \multirow[t]{4}{*}{ CG } & $6 \mathrm{~mm}$ & T1 & 4 & 3 & 4 & \\
\hline & & T2 & 4 & 3 & 4 & 0.5 \\
\hline & $9 \mathrm{~mm}$ & T1 & 4 & 2.3 & 4 & \\
\hline & & T2 & 4 & 3 & 4 & 0.129 \\
\hline
\end{tabular}

Table 2 - Intragroup Comparison (Wilcoxon) 
Table 3

\begin{tabular}{|c|c|c|c|c|c|c|}
\hline & & & Median & $25 \%$ & $75 \%$ & $\mathbf{p}$ \\
\hline & $3 \mathrm{~mm}$ & CG & 4 & 1 & 4 & \\
\hline & & EG & 2 & 2 & 3.8 & 0.16 \\
\hline \multirow[t]{6}{*}{ T1 } & $6 \mathrm{~mm}$ & CG & 4 & 3 & 4 & \\
\hline & & EG & 3 & 2 & 4 & 0.126 \\
\hline & $9 \mathrm{~mm}$ & CG & 4 & 2.3 & 4 & \\
\hline & & $E G$ & 4 & 2 & 4 & 0.964 \\
\hline & $3 \mathrm{~mm}$ & CG & 4 & 2.5 & 4 & \\
\hline & & EG & 4 & 3 & 4 & 0.829 \\
\hline \multirow[t]{6}{*}{ T2 } & $6 \mathrm{~mm}$ & CG & 4 & 3 & 4 & \\
\hline & & EG & 4 & 3 & 4 & 0.702 \\
\hline & $9 \mathrm{~mm}$ & CG & 4 & 3 & 4 & \\
\hline & & $E G$ & 4 & 3.5 & 4 & 0.826 \\
\hline & $3 \mathrm{~mm}$ & CG & 0 & 0 & 0 & \\
\hline & & EG & 1 & 0 & 2 & $0.007^{*}$ \\
\hline \multirow[t]{4}{*}{ T2-T1 } & $6 \mathrm{~mm}$ & CG & 0 & 0 & 0 & \\
\hline & & EG & 0 & 0 & 1 & $0.027^{*}$ \\
\hline & $9 \mathrm{~mm}$ & CG & 0 & 0 & 0.8 & \\
\hline & & EG & 0 & 0 & 0 & 0.99 \\
\hline
\end{tabular}

Table 3 - Intergroup Comparison (Mann-Whitney) 


\section{FINAL CONSIDERATIONS}

Cleft rehabilitation is challenging and health professionals' biggest efforts are often on the correction of skeletal Class III profile due to maxillary growth impairment. Technology has been providential on better resolutions for this problem. BAMP therapy is an example of contemporary approach with distinct and unprecedented results for orthopedic treatment of maxillary retrusion. This paper relevantly advises cleft care professionals that protruding the maxilla orthopedically with miniplates is feasible and not harmful to the alveolar bone graft, even when not fully developed. The maxilla of the patient with cleft appears to be protruded behaving as an undivided bone, with no compression influence on the ABG area along therapy. 



\section{REFERENCES}

ÅBYHOLM, F. E.; BERGLAND, O.; SEMB, G. Secondary bone grafting of alveolar clefts: A surgical/orthodontic treatment enabling a non-prosthodontic rehabilitation in cleft lip and palate patients. Scandinavian Journal of Plastic and Reconstructive Surgery and Hand Surgery, v. 15, n. 2, p. 127-140, 1981.

BACCETTI, T.; DE CLERCK, H. J.; CEVIDANES, L. H.; FRANCHI, L. Morphometric analysis of treatment effects of bone-anchored maxillary protraction in growing Class III patients. European Journal of Orthodontics, v. 33, n. 2, p. 121-125, 1 abr. 2011.

BACCETTI, T.; MCGILL, J. S.; FRANCHI, L.; MCNAMARA, J. A.; TOLLARO, I. Skeletal effects of early treatment of Class III malocclusion with maxillary expansion and face-mask therapy. American Journal Of Orthodontics And Dentofacial Orthopedics, v. 113, n. 3, p. 333-343, Mar. 1998.

BERGLAND, O.; SEMB, G.; ABYHOLM, F. E. Elimination of the residual alveolar cleft by secondary bone grafting and subsequent orthodontic treatment. The Cleft Palate Journal, v. 23, n. 3, p. 175-205, July 1986.

BOYARSKIY, S.; CHOI, H. J.; PARK, K. Evaluation of alveolar bone support of the permanent canine in cleft and noncleft patients. Cleft Palate-Craniofacial Journal, v. 43 , n. 6, p. 678-682, Nov. 2006.

BOYNE, P. J.; SANDS, N. R. Secondary bone grafting of residual alveolar and palatal defects. Oral and Maxillofacial Surgery, v. 30, n. 2, p. 87-92, Fev. 1972.

CEVIDANES, L.; BACCETTI, T.; FRANCHI, L.; MCNAMARA, J. A.; DE CLERCK, H. Comparison of two protocols for maxillary protraction: Bone anchors versus face mask with rapid maxillary expansion. Angle Orthodontist, v. 80, n. 5, p. 799-806, Sept. 2010.

CORNELIS, M. A.; SCHEFFLER, N. R.; MAHY, P.; SICILIANO, S.; DE CLERCK, H. J.; TULLOCH, J. F. C. Modified Miniplates for Temporary Skeletal Anchorage in Orthodontics: Placement and Removal Surgeries. Journal of Oral and Maxillofacial Surgery, v. 66, n. 7, p. 1439-1445, 2008.

DA SILVA FILHO, O. G.; TELES, S. G.; OZAWA, T. O.; FILHO, L. C. Secondary bone graft and eruption of the permanent canine in patients with alveolar clefts: literature review and case report. The Angle orthodontist, v. 70, n. 2, p. 174-8, Abr. 2000.

DASKALOGIANNAKIS, J.; MEHTA, M. The need for orthognathic surgery in patients with repaired complete unilateral and complete bilateral cleft lip and palate. The Cleft Palate-Craniofacial Journal, v. 46, n. 5, p. 498-502, 2009.

DE CLERCK, E. E. B.; SWENNEN, G. R. J. Success rate of miniplate anchorage for 
bone anchored maxillary protraction. The Angle Orthodontist, v. 81, n. 6, p. 1010 3, Nov. 2011.

DE CLERCK, H. J.; CORNELIS, M. A.; CEVIDANES, L. H.; HEYMANN, G. C.; TULLOCH, C. J. F. Orthopedic Traction of the Maxilla With Miniplates: A New Perspective for Treatment of Midface Deficiency. Journal of Oral and Maxillofacial Surgery, v. 67, n. 10, p. 2123-2129, 2009.

DE CLERCK, H. J.; PROFFIT, W. R. Growth modification of the face: A current perspective with emphasis on Class III treatment. American Journal of Orthodontics and Dentofacial Orthopedics, 2015 Jul;148(1):37-46.

HAMMOUDEH, J. A.; FAHRADYAN, A.; GOULD, D. J.; LIANG, F.; IMAHIYEROBO, T.; URBINELLI, L.; NGUYEN, J. A. T.; MAGEE, W.; YEN, S.; URATA, M. M. A comparative analysis of recombinant human bone morphogenetic protein-2 with a demineralized bone matrix versus iliac crest bone graft for secondary alveolar bone grafts in patients with cleft lip and palate: Review of 501 cases. Plastic and Reconstructive Surgery, v. 140, n. 2, p. 318e-325e, 2017.

KANG, N. H. Current methods for the treatment of Alveolar cleft. Archives of Plastic Surgery, v. 44, n. 3, p. 188-193, 2017.

LIANG, F.; YEN, S. L. K.; IMAHIYEROBO, T.; SANBORN, L.; YEN, L.; YEN, D.; NAZARIAN, S.; JEDRZEJEWSKI, B.; URATA, M.; HAMMOUDEH, J. ThreeDimensional Cone Beam Computed Tomography Volumetric Outcomes of rhBMP2/Demineralized Bone Matrix versus lliac Crest Bone Graft for Alveolar Cleft Reconstruction. Plastic and reconstructive surgery, v. 140, n. 4, p. 767-774, 2017.

NORMANDO, A. D. C.; DA SILVA FILHO, O. G.; CAPELOZZA FILHO, L. Influence of surgery on maxillary growth in cleft lip and/or palate patients. Journal of CranioMaxillofacial Surgery, v. 20, n. 3, p. 111-118, Abr. 1992.

SANTIAGO, P. E.; SCHUSTER, L. A.; LEVY-BERCOWSKI, D. Management of the alveolar cleft. Clinics in Plastic Surgery, 2014 Apr;41(2):219-32.

SOUSA, A.; DEVARE, S.; GHANSHANI, J. Psychological issues in cleft lip and cleft palate. Journal of Indian Association of Pediatric Surgeons, v. 14, n. 2, p. 55, Abr. 2009.

TURVEY, T. A.; VIG, K.; MORIARTY, J.; HOKE, J. Delayed bone grafting in the cleft maxilla and palate: A retrospective multidisciplinary analysis. American Journal of Orthodontics, v. 86, n. 3, p. 244-256, Set. 1984.

WU, C.; PAN, W.; FENG, C.; SU, Z.; DUAN, Z.; ZHENG, Q.; HUA, C.; LI, C. Grafting materials for alveolar cleft reconstruction: a systematic review and best-evidence synthesis. International Journal of Oral and Maxillofacial Surgery, v. 47, n. 3, p. 345-356, 2018. 
YATABE, M.; GARIB, D.; FACO, R.; DE CLERCK, H.; SOUKI, B.; JANSON, G.; NGUYEN, T.; CEVIDANES, L.; RUELLAS, A. Mandibular and glenoid fossa changes after bone-anchored maxillary protraction therapy in patients with UCLP: A 3-D preliminary assessment. Angle Orthodontist, v. 87, n. 3, p. 423-431, 26 Set. 2017a. YATABE, M.; GARIB, D. G.; FACO, R. A. de S.; DE CLERCK, H.; JANSON, G.; NGUYEN, T.; CEVIDANES, L. H. S.; RUELLAS, A. C. Bone-anchored maxillary protraction therapy in patients with unilateral complete cleft lip and palate: 3dimensional assessment of maxillary effects. American Journal of Orthodontics and Dentofacial Orthopedics, v. 152, n. 3, p. 327-335, Set. 2017b.

ZOUHARY, K. J. Bone Graft Harvesting From Distant Sites: Concepts and Techniques. Oral and Maxillofacial Surgery Clinics of North America, 2010 Aug;22(3):301-16. 
